\title{
Effect of DR4 promoter methylation on the TRAIL-induced apoptosis in lung squamous carcinoma cell
}

\author{
WENWU WANG ${ }^{1,2}$, XIAOYAN $\mathrm{QI}^{2}$ and MINGHUA WU ${ }^{1,3}$ \\ ${ }^{1}$ Hunan Provincial Tumor Hospital and The Affiliated Tumor, Hospital of Xiangya Medical School, Central South University, \\ Changsha, Hunan 410078; ${ }^{2}$ Department of Medicine Oncology, Fuzhou General Hospital of Nanjing Military Command, \\ Fuzhou, Fujian 350025; ${ }^{3}$ Cancer Research Institute, Central South University, Changsha, Hunan 410078, P.R. China
}

Received March 23, 2015; Accepted July 7, 2015

DOI: $10.3892 /$ or.2015.4170

\begin{abstract}
The aim of the present study was to examine the relationship between DR4 methylation status and gene expression and to determine whether DR4 methylation status affects TRAIL-induced apoptosis in lung squamous carcinoma cells. MSP, RT-PCR and western blot analysis were applied to detect the methylation status and gene expression. An MTT assay was used to detect the cell proliferation inhibition rate and flow cytometry was utilized to detect the apoptotic rate. The results showed that there was no association of the apoptotic rate with the clinicopathological characteristics for $80.6 \%$ of 36 lung squamous carcinoma patients in the methylation status $(\mathrm{P}>0.05)$. In the lung squamous carcinoma patients, the probability of DR4 low expression was approximately 58.3\%, which may be associated with DR4 promoter methylation. The results also showed that a low expression of DR4 was correlated with the prognosis of patients. The in vitro experiments suggested DR4 genes of H226 and SK-MES-1 cells were in the methylation status and their mRNA and proteins had a low expression. Following intervention with 5-Aza-CdR, the DR4 genes of H226 and SK-MES-1 cells were in the unmethylation status and their mRNA and protein expression was significantly upregulated compared with the pre-interference ones, with differences being statistically significant $(\mathrm{P}<0.05)$. In addition, following interference with 5-Aza-CdR, H226 and SK-MES-1 cells became significantly sensitive to TRAIL $(\mathrm{P}<0.05)$. The results revealed 5-Aza-CdR was able to reverse DR4 methylation status to upregulate its expression, thereby increasing the TRAIL-induced apoptosis in lung squamous carcinoma cells. Therefore, combining 5-Aza-CdR and TRAIL is a new strategy for treating lung squamous carcinoma.
\end{abstract}

Correspondence to: Professor Minghua Wu, Cancer Research Institute, Central South University, 110 Xiangya Road, Changsha, Hunan 410078, P.R. China

E-mail: wuminghua554@aliyun.com

Key words: lung squamous carcinoma, DR4 gene, TRAIL, methylation, 5-Aza-CdR

\section{Introduction}

Almost $85 \%$ of lung carcinoma patients suffer from non-small cell lung cancer, while patients with lung squamous carcinoma account for 25-30\% of patients with non-small cell lung cancer (1). At present, surgery remains the main treatment method for lung squamous carcinoma. However, should metastasis occur, treatment is rendered ineffective and the prognosis is poor. Chemotherapy efficacy is relatively limited in treating patients with metastasis lung squamous carcinoma, and the patient 5-year survival rate remains at $<15 \%(2,3)$, while a targeted drug with good efficacy for lung squamous carcinoma remains to be identified. As a result, identification of a new and efficient antineoplastic agent with small toxicity has become a research hotspot for lung squamous carcinoma treatment.

Tumor necrosis factor-related apoptosis-inducing ligand (TRAIL) is a member of the tumor necrosis factor (TNF) superfamily. Previous findings (4-6) have shown that TRAIL induces apoptosis of a variety of tumor cells, but exhibits no significant toxicity to normal tissues $(7,8)$. Therefore, studies have focused on the antitumor effect of TRAIL, demonstrating a broad application prospect in the field of targeted therapy for carcinoma. TRAIL-induced apoptosis of carcinoma cells is mainly achieved by combining with death receptor 4 (DR4) and death receptor 5 (DR5) to recruit the fas-associated death domain (FADD) and form a death-inducing signaling complex (DISC), initiating a cascade reaction and triggering cell apoptosis (9-12). Therefore, a high expression of DR4 and DR5 can promote the TRAIL-induced apoptosis of carcinoma cells. However, most carcinoma cells are resistant to TRAIL-induced apoptosis, limiting its clinical application $(13,14)$. Previous in-depth investigations on the mechanism of tumor cells for resisting TRAIL (15-19), have identified that drug resistance may be associated with the hypermethylation of the DR4 gene promoter. 5-Aza-2'-deoxycytidine (5-Aza-CdR), also known as decitabine, is a specific methylation inhibitor, which is mainly used for the clinical treatment of myelodysplastic syndrome and chronic myelogenous leukemia, and has achieved significant results (20-22). It has been reported that 5-Aza-CdR is capable of reversing the hypermethylation status of carcinoma cells, recover the expression of related genes and reverse carcinoma drug resistance (23-25). Thus, the aim of the present study was to examine lung squamous carcinoma and investigate 
whether the DR4 gene promoter methylation status affected the TRAIL-induced apoptosis of lung squamous carcinoma cells.

\section{Materials and methods}

Materials used in the in vitro experiments. H226, SK-MES-1 and H520 lung squamous carcinoma cell lines were procured from Beinuo Biotechnology Co., Ltd. (Shanghai, China), the main reagent TRAIL was donated by Qiaer Biotechnology Co., Ltd.(Shanghai, China), 5-Aza-CdR, MTT and DMSO were purchased from Sigma (St. Louis, MO, USA), RPMI-1640 and DMEM high-glucose cell culture medium as well as fetal bovine serum were purchased from Gibco-Life Technologies (Carlsbad, CA, USA). The EZ DNA Methylation-Gold ${ }^{\mathrm{TM}}$ kit was procured from Zymo (Orange, CA, USA), the DNA extraction kit, TRIzol reagent, reverse transcription kit, TaqPCR SuperMix and DNA markers were purchased from Beijing TransGen Biotech Co., Ltd. and the Annexin-V FITC/PI apoptosis detection kits were purchased from BD Biosciences (Bedford, MA, USA). Rabbit anti-human DR4 polyclonal antibodies and rabbit anti-human $\beta$-actin polyclonal antibodies are purchased from Abcam (Cambridge, MA, USA). Horseradish peroxidase-labeled goat anti-rabbit $\operatorname{IgG}(\mathrm{H}+\mathrm{L})$ antibodies were purchased from Beyotime Biotechnology Co., Ltd. (Shanghai, China) and rat/rabbit universal secondary antibodies were purchased from MXB Biotechnology Co., Ltd. (Fuzhou, China). PCR primers were designed and produced by Shanghai Invitrogen Biotechnology Co., Ltd. (Shanghai, China).

Patients participating in the in vivo experiments. Thirty-six surgical specimens were obtained from patients diagnosed with lung squamous carcinoma at the Fuzhou General Hospital of Nanjing Military Command (Fujian, China) between March 2010 and March 2013. There were 35 male patients and 1 female patient (age range, $42-82$ years; median, 61 and average age, 61.6). Of the 36 patients, 32 had a history of smoking. According to AJCC staging in 2010, 6 patients were classified as stage-IA lung squamous carcinoma, 4 as stage-IB carcinoma, 14 as stage-IIA carcinoma, 2 as stage-IIB carcinoma, 8 as stage-IIIA carcinoma, 1 as stage-IIIB carcinoma and 1 as stage-IV carcinoma. According to the pathological differentiation degree, 3 patients exhibited high degree, 6 patients high and middle, 14 patients middle, 9 patients low and middle, and 4 patients exhibited low degree. The patients did not undergo radio- or chemotherapy prior to surgery. However, all 36 patients accepted radio- and chemotherapy as adjuvant therapy following surgery, with 29 of the patients eventually exhibiting disease progression or succumbed to the disease.

Immunohistochemistry. The Elivision two-step method was employed to detect the expression of clinical tissue DR4. The detection procedure was as follows: After deparaffinization and hydration, paraffin-embedded tissue sections were placed into citrate buffer $(10 \mathrm{mmol} / \mathrm{l}, \mathrm{pH}$ 6.0) for heating in a water bath for $15 \mathrm{~min}$ for antigen retrieval. After cooling, the section was soaked and incubated with $3 \% \mathrm{H}_{2} \mathrm{O}_{2}$ for 10 min, to block the activity of endogenous peroxidase. After rinsing three times with PBS (3 min each time), the section was immersed in rabbit anti-human DR4 polyclonal antibodies (purchased from Abcam), diluted at a ratio of 1:25 and then incubated for
$3 \mathrm{~h}$ at room temperature. After rinsing three times with PBS, with a drop of polymer enhancer (reagent $A$ ) was added to each section, incubated for $20 \mathrm{~min}$ at room temperature and rinsed with PBS three times. A drop of HRP anti-rat/rabbit polymer (reagent B) was added to each slice, incubated for $30 \mathrm{~min}$ at room temperature, rinsed with PBS, developed with DAB, re-stained with hematoxylin, differentiated with $0.1 \% \mathrm{HCl}$, rinsed with tap water, stained with Acian blue solution, dehydrated and dried with graded alcohol, sealed with neutral gum and dried for observation. A DR4-positive signal was considered brown granular, located in the cytoplasm with staining intensity and divided into four grades:,,++++++ and ++++ .

Methylation-specific PCR (MSP). The cell/tissue DNA was extracted according to the DNA extraction kit. After quantification of DNA, 500 ng DNA was extracted for methylation modification using the EZ DNA Methylation-Gold ${ }^{\mathrm{TM}}$ kit. Taking it as a template, methylated and unmethylated primers were applied for PCR amplification. Methylation-specific primers $(23,24)$ used were: upstream, 5'-TTCGAATTTCGG GAGCGTAGC-3' and downstream, 5'-GTAATTCAATCC TCCCCG CGA-3' (fragments, 91 bp). Unmethylated specific primers used were: upstream, 5'-GTAGTGATTTTGAAT TTTGGGAGTGTAGT-3' and downstream, 5'-CTCATAATT CAATCCCCACAA-3' (fragments, $102 \mathrm{bp}$ ). The PCR reaction conditions were: $95^{\circ} \mathrm{C}$ for $5 \mathrm{~min}, 95^{\circ} \mathrm{C}$ for $30 \mathrm{sec}, 57^{\circ} \mathrm{C}$ for $30 \mathrm{sec}$ and $72^{\circ} \mathrm{C}$ for $40 \mathrm{sec}$, with a total of 30 cycles, and $72^{\circ} \mathrm{C}$ for an extension of $5 \mathrm{~min}$. Amplified products were analyzed with $2 \%$ agarose gel electrophoresis and gel imaging and observed and photographed under ultraviolet light. It was found that methylated primers were positive after amplification and unmethylated primers were negative after amplification, and were deemed exhaustive methylation. Additionally, methylated and unmethylated primers were found to have positive bands with partial methylation after amplification, but remained positive in methylation. By contrast, when methylated primers were negative after amplification, methylation was deemed to be negative only when unmethylated primers were positive after amplification. This experiment was repeated three times.

Cell and adherent culture. $\mathrm{H} 226$ and $\mathrm{H} 520$ cells were cultured in RPMI-1640 culture medium containing 10\% FBS and $10 \mathrm{U} / \mathrm{ml}$ penicillin and streptomycin, while SK-MES-1 cells were cultured in DMEM (high glucose) culture medium containing $10 \%$ FBS and $100 \mathrm{U} / \mathrm{ml}$ penicillin and streptomycin. The cells were incubated in $5 \% \mathrm{CO}_{2}$ at $37^{\circ} \mathrm{C}$, with the culture medium replaced once every two days. After passage for 1 day, $5 \mu \mathrm{mol} / 15$-azacytidine was, respectively, added to the culture flasks to continue culturing for 2 days. After culture termination, the cells without intervention by adding 5 -azacytidine were considered the control group.

Reverse transcription-PCR (RT-PCR). Three lung squamous carcinoma cells at the exponential phase prior to and following treatment with 5-Aza-CdR were used. The total RNA of cells was extracted using TRIzol reagent and reverse transcribed to become cDNA using a reverse transcription kit. This was utilized as a template for the PCR amplification. DR4 primers used were: upstream, 5'-AAGTCCCTGCACCACGAC-3' and downstream, 5'-CCACAACCTGAGCCGATG-3' (fragments, 


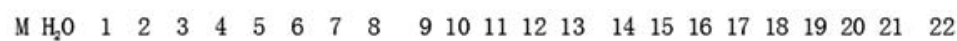

m

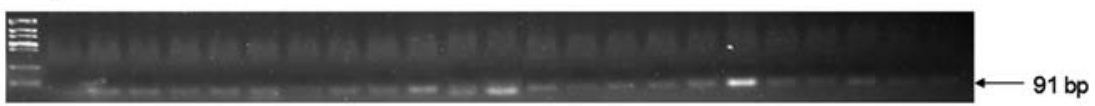

$\mathrm{u}$

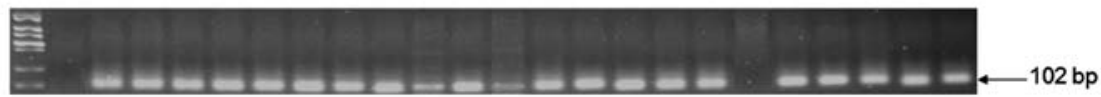

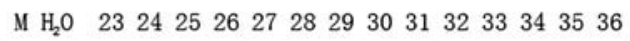

$\mathrm{m}$

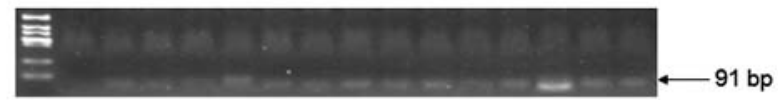

u

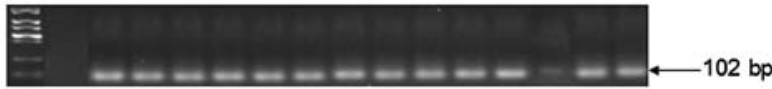

Figure 1. DR4 gene promoter methylation status of 36 patients with lung squamous carcinoma. M, DNA marker; $\mathrm{H}_{2} \mathrm{O}$, blank control group; m, methylation; $\mathrm{u}$, unmethylation.

$256 \mathrm{bp})$, and GAPDH primers: upstream, 5'-TGCACCACC AACTGCTTAGC-3' and downstream, 5'-GGCATGGAC TGTGGTCATGAG-3' (fragments, $100 \mathrm{bp}$ ). The PCR reaction conditions were: $96^{\circ} \mathrm{C}$ for $5 \mathrm{~min}, 96^{\circ} \mathrm{C}$ for $30 \mathrm{sec}, 57^{\circ} \mathrm{C}$ for $30 \mathrm{sec}$ and $72^{\circ} \mathrm{C}$ for $40 \mathrm{sec}$, with a total of 35 cycles, and $72^{\circ} \mathrm{C}$ for an extension of $5 \mathrm{~min}$. Amplified products were analyzed using $1.5 \%$ agarose gel electrophoresis and gel imaging, and observed and photographed under ultraviolet light. Quantity One software was employed to analyze the gray value of the electrophoretic band and GAPDH was used as a standardized internal control.

Western blot analysis. Three lung squamous carcinoma cells at the exponential phase prior to and following treatment with 5-Aza-CdR were used. Proteins were extracted by adding protein lysate to lyse cells and quantified using the BCA method. The cell protein was separated by electrophoresis using 10\% SDS-PAGE and transmembrane after electrophoresis. After successful transfer, the membranes were blocked for $1 \mathrm{~h}$ with $5 \%$ skim milk and incubated overnight at $4^{\circ} \mathrm{C}$ with DR4 and $\beta$-actin primary antibodies, respectively. Primary antibodies were washed, while secondary antibodies were incubated for $1.5 \mathrm{~h}$. ECL was used for color development and $\beta$-actin was considered as a standardized internal control.

MTT detection. H226 and SK-MES-1 cells at the exponential phase prior to and following treatment with 5 -Aza-CdR were removed and inoculated into the 96-well plate at $1 \times 10^{5} / \mathrm{ml}$ and $100 \mu \mathrm{l} /$ well. Six parallel wells were used for each group and cultivated for $24 \mathrm{~h}$, after which the supernatant was discarded. Culture medium $(100 \mu \mathrm{l})$ containing different concentrations of the drug (TRAIL concentrations of $0.01,0.05,0.10,0.50,1.00$ and $5.00 \mu \mathrm{g} / \mathrm{ml}$ ) was added. Each experiment established the blank and control groups. After the drug treatment for 24 and $48 \mathrm{~h}, 100 \mu 10.5 \mathrm{mg} / \mathrm{ml}$ MTT solution was added to each well. After termination of culture after $4 \mathrm{~h}$ of continuous incubation, the liquid in each well was gently aspirated and $150 \mu 1$ DMSO was added to each well. The liquid was then agitated for 10 min to dissolve the crystal completely. Subsequently, the absorbance value (A) of each well was measured at $490 \mathrm{~nm}$ wavelength of the enzyme-linked immunosorbent assay. The experiment was repeated three times. The cell proliferation inhibition rate was calculated according to the drug concentration, using the formula: (1-average A value of the experimental group/average A value of the control group) x100\%.

Flow cytometry. $\mathrm{H} 226$ and SK-MES-1 cells were treated with $0.5 \mu \mathrm{g} / \mathrm{ml}$ TRAIL (TRAIL group) and $5 \mu \mathrm{mol} / 15$-Aza-CdR (5-Aza-CdR group) for $24 \mathrm{~h}$, while the joint group was treated with $1 \mu \mathrm{g} / \mathrm{ml}$ TRAIL for $24 \mathrm{~h}$ after previously being treated with $5 \mu \mathrm{mol} / 15-\mathrm{Aza}-\mathrm{CdR}$ for $48 \mathrm{~h}$. The cells were collected and rinsed with PBS twice. The cell apoptotic rate was detected according to the instructions of the Annexin-V FITC/PI apoptosis detection kit. The experiment was repeated three times.

Statistical analysis. Using SPSS18 statistical software, the measurement data were presented as mean \pm standard deviation (means $\pm \mathrm{SD}$ ). The Spearman rank correlation analysis was used to determine the dose-effect relationship. The t-test was used to compare the differences among the various groups. The $\chi^{2}$ or Fisher's exact test was employed to detect the relationship between DR4 gene promoter methylation statuses and clinicopathological characteristics of patients with lung squamous carcinoma. The $\kappa$ value was used to assess the relationship between the DR4 gene promoter methylation and DR4 protein expression of patients with lung squamous carcinoma. To determine the relationship between the expression of DR4 protein and prognosis of the patients with lung squamous carcinoma, the Kaplan-Meier was employed to assess the survival rate, while the log-rank and Breslow tests were utilized to assess the survival rate differences of patients from different groups. The bilateral probability test denoted that $\mathrm{P}<0.05$ indicates statistical significance.

\section{Results}

The relationship between $D R 4$ gene promoter methylation statuses and clinicopathological characteristics of patients with lung squamous carcinoma. The MSP results showed that $80.6 \%$ of 36 lung squamous carcinoma patients exhibited positive methylation status, 1 patient exhibited hypermethylation status, 28 patients exhibited partial methylation status, while the remaining 7 patients did not exhibit positive methylation status, indicating lung squamous carcinoma exhibited a high methylation modification (Fig. 1). At the same time, 


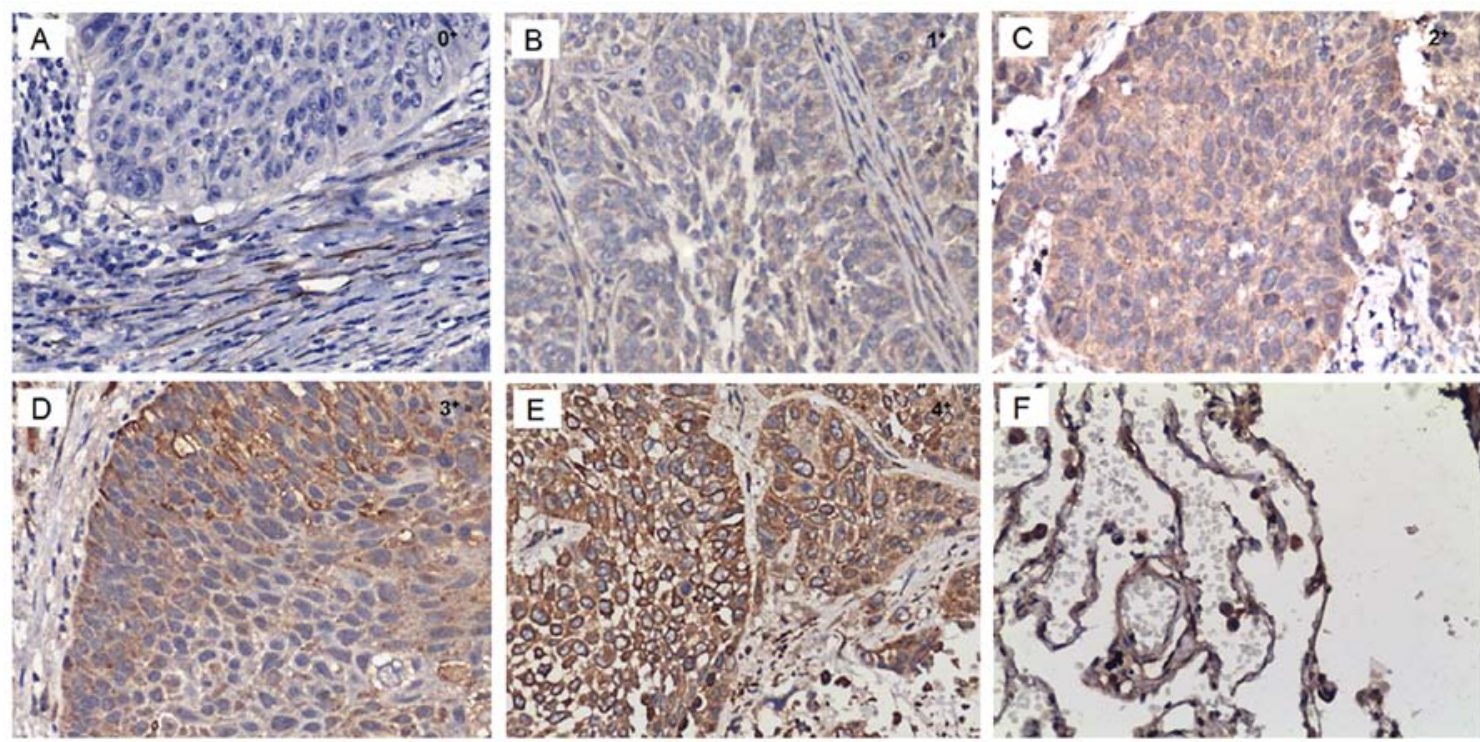

Figure 2. DR4 protein expression of lung squamous carcinoma (Elivision two-step x200 times). (A) Non-expression (0) of DR4, (B) low-expression (+), (C and D) moderate-expression (++ to +++), (E) normal high expression (++++) and (F) normal tissue high expression (++++).

Table I. Relationship between DR4 gene promoter methylation status and clinicopathological characteristics of patients with lung squamous carcinoma.

\begin{tabular}{|c|c|c|c|c|}
\hline $\begin{array}{l}\text { Clinicopathological } \\
\text { parameters }\end{array}$ & $\mathrm{n}$ & $\mathrm{m}$ & $\mathrm{u}$ & P-value \\
\hline Age (years) & & & & 1.000 \\
\hline$\leq 60$ & 17 & 14 & 3 & \\
\hline$>60$ & 19 & 15 & 4 & \\
\hline Gender & & & & 1.000 \\
\hline Male & 35 & 28 & 7 & \\
\hline Female & 1 & 10 & & \\
\hline Smoking history & & & & 0.408 \\
\hline$\leq 20$ & 19 & 14 & 5 & \\
\hline$>20$ & 17 & 15 & 2 & \\
\hline $\begin{array}{l}\text { Pathological degree } \\
\text { of differentiation }\end{array}$ & & & & 0.333 \\
\hline $\begin{array}{l}\text { High-middle } \\
\text { differentiation }\end{array}$ & 9 & 6 & 3 & \\
\hline $\begin{array}{l}\text { Low-middle } \\
\text { differentiation }\end{array}$ & 27 & 23 & 4 & \\
\hline TNM stage & & & & 0.076 \\
\hline Early & 26 & 23 & 3 & \\
\hline Stage-I & 10 & 8 & 2 & \\
\hline Stage -II & 16 & 16 & 1 & \\
\hline Middle and advanced & 10 & 6 & 4 & \\
\hline Stage -III & 9 & 5 & 4 & \\
\hline Stage -IV & 1 & 1 & 0 & \\
\hline Lymph node metastasis & & & & 0.674 \\
\hline Positive & 21 & 16 & 5 & \\
\hline Negative & 15 & 13 & 2 & \\
\hline
\end{tabular}

$\mathrm{m}$, methylation; u, unmethylation.
Table II. Relationship between DR4 gene promoter methylation and DR4 protein expressions of patients with lung squamous carcinoma.

\begin{tabular}{|c|c|c|c|c|c|}
\hline \multirow[b]{2}{*}{ IHC } & \multicolumn{3}{|c|}{$\begin{array}{l}\text { Methylation } \\
\text { status }\end{array}$} & \multirow[b]{2}{*}{$\kappa$-value } & \multirow[b]{2}{*}{ P-value } \\
\hline & $\mathrm{n}$ & $\mathrm{m}$ & $\mathrm{u}$ & & \\
\hline $\begin{array}{l}\text { Low expression } \\
(- \text { to }+) \\
\text { High expression } \\
(++ \text { to }++++)\end{array}$ & 21 & 20 & $\begin{array}{l}1 \\
6\end{array}$ & 0.381 & 0.008 \\
\hline
\end{tabular}

IHC, immunohistochemistry; m, methylation; $\mathrm{u}$, unmethylation.

the results confirmed that the DR4 gene promoter methylation status did not correlate with the clinicopathological characteristics, such as age, gender, smoking, pathological grade, TNM stage and lymph node metastasis, of patients suffering from lung squamous carcinoma $(\mathrm{P}>0.05)$ (Table I).

The relationship between DR4 gene promoter methylations and DR4 protein expression of the patients with lung squamous carcinoma. DR4 protein expression was assessed using immunohistochemistry based on the staining intensity. Four cases of 36 clinical samples exhibited 0 DR4 protein expression, 17 exhibited,+ 10 exhibited ++ to +++ and 5 exhibited ++++ (Fig. 2). The probability of DR4 low expression of patients with lung squamous carcinoma was $58.3 \%$ (21 of 36 samples). The results confirmed that the DR4 protein expression levels of the patients with lung squamous carcinoma were associated with their gene promoter methylation degrees $(\mathrm{P}<0.05)$ (Table II). This finding suggested that the probability of low DR4 expression of patients with lung squamous carcinoma was relatively high, which may be associated with gene promoter methylation. 


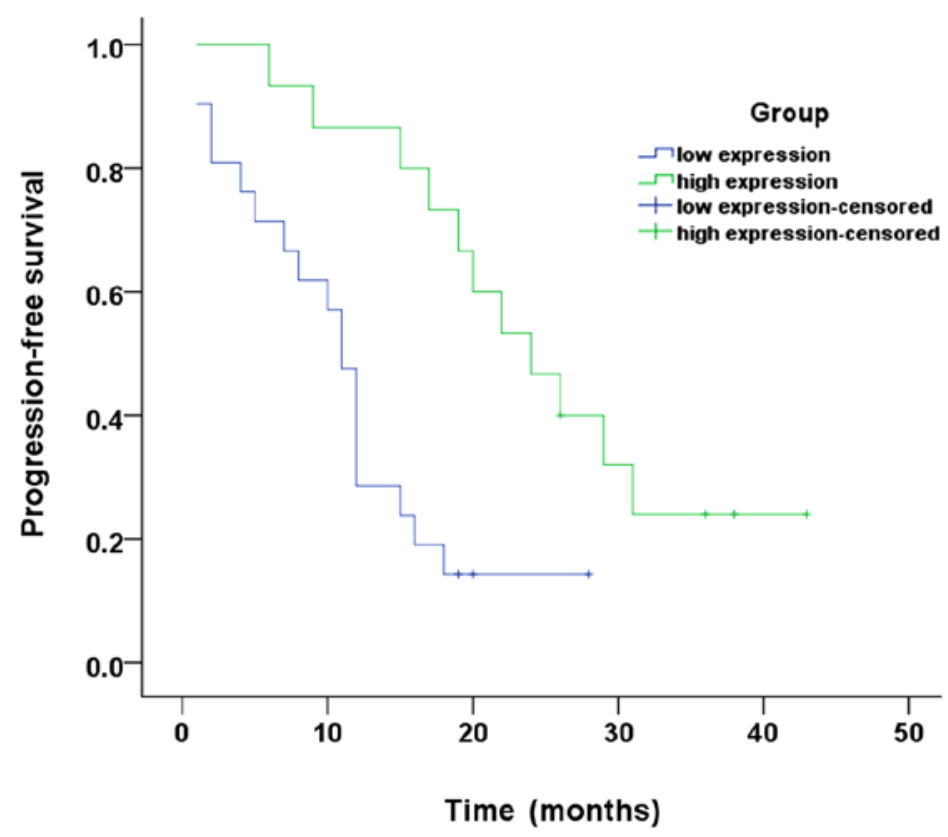

Figure 3. Relationship between DR4 protein expression and prognosis of patients with lung squamous carcinoma.

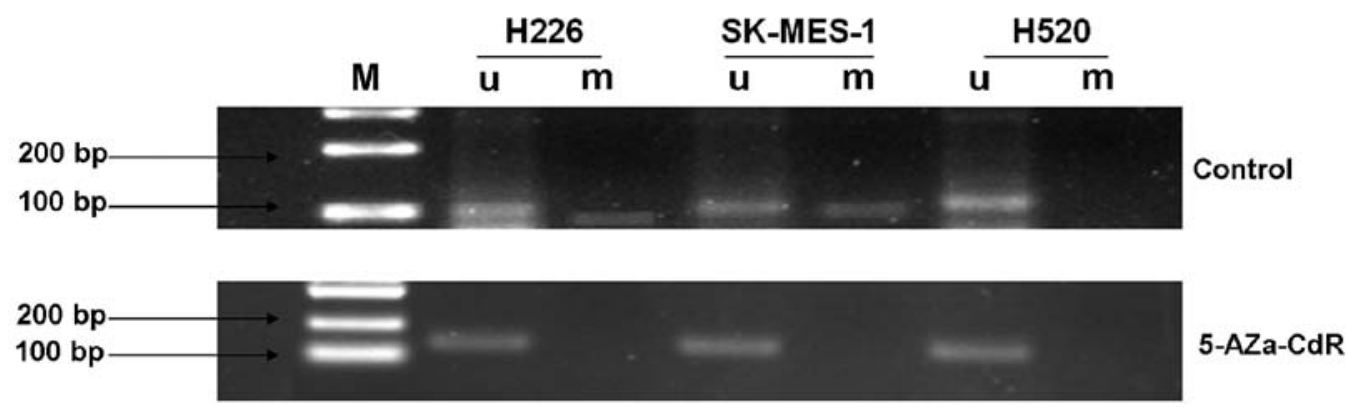

Figure 4. DR4 gene methylation status of H226, SK-MES-1 and H520 cells prior to and following interference with 5-Aza-CdR. M, DNA m1arker; m, methylation amplification; $\mathrm{u}$, unmethylation amplification; 5-AZ, 5-azacytidine.

The relationship between DR4 protein expression and prognosis of patients with lung squamous carcinoma. In the group of low DR4 expression, 21 patients with lung squamous carcinoma had a median PFS of 11 months (95\% CI: 9.505-12.495); while in the high DR4 expression group, 15 patients with lung squamous carcinoma had a median PFS of 25.653 months (95\% CI: 19.631-31.676), based on results of the log rank test, $\chi^{2}=9.494, \mathrm{P}=0.002$ and Breslow test, $\chi^{2}=10.515, \mathrm{P}=0.001$; or combined, $\mathrm{P}<0.05$ (Fig. 3). Thus, the two groups of PFS time difference were statistically significant. The result showed that the prognosis of patients with a high DR4 expression of lung squamous carcinoma was lower than that of the patients with a low DR4 expression.

$D R 4$ gene promoter region CpG island methylation status. The MSP result showed that the DR4 promoter region in $\mathrm{H} 226$ and SK-MES-1 cells was partly methylated while H520 exhibited a non-methylated state. Following treatment with 5-Aza-CdR, the DR4 promoter region in H226 and SK-MES-1 cells was altered from a partly methylated to a non-methylated status, while H520 remained in the non-methylated state (Fig. 4).
DR4 mRNA expression. The DR4 mRNA relative expression (means $\pm \mathrm{SD}$ ) of H226, SK-MES-1 and H520 cells prior to and following interference with 5-azacytidine was identified as $0.245 \pm 0.005,0.899 \pm 0.011,0.139 \pm 0.009,0.528 \pm 0.012$, $0.789 \pm 0.011$ and $0.803 \pm 0.013$, respectively. The results showed that priro to interference with 5-azacytidine, the DR4 mRNA expression of $\mathrm{H} 226$ and SK-MES-1 cells was low whereas that of H520 cells was high. By contrast, following interference with 5-azacytidine, the DR4 mRNA expression of H226 and SK-MES-1 cells was significantly enhanced compared with the previous levels and the differences were statistically significant $(\mathrm{P}<0.05)$. However, the DR4 mRNA expression of H520 cells was slightly increased compared with the previous levels, and the differences were not statistically significant (Figs. 5 and 6).

DR4 protein expression. The DR4 protein expression (means \pm SD) of H226, SK-MES-1 and H520 cells prior to and following interference with 5-azacytidine was identified as $0.217 \pm 0.019,0.415 \pm 0.031,0.264 \pm 0.021,0.418 \pm 0.036$, $0.426 \pm 0.028$ and $0.419 \pm 0.03$, respectively. The results showed that prior to interference with 5-azacytidine, DR4 protein 


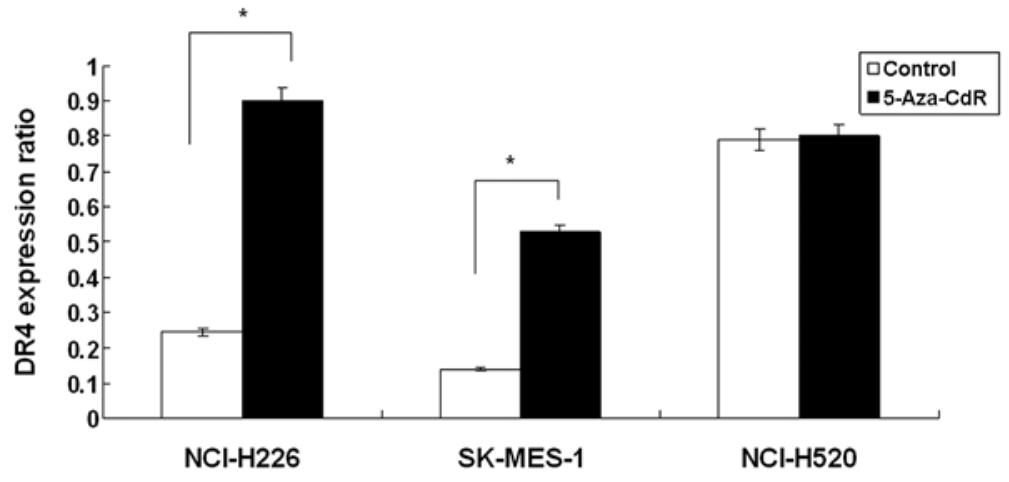

Figure 5. DR4 mRNA expression of H226, SK-MES-1 and H520 cells.

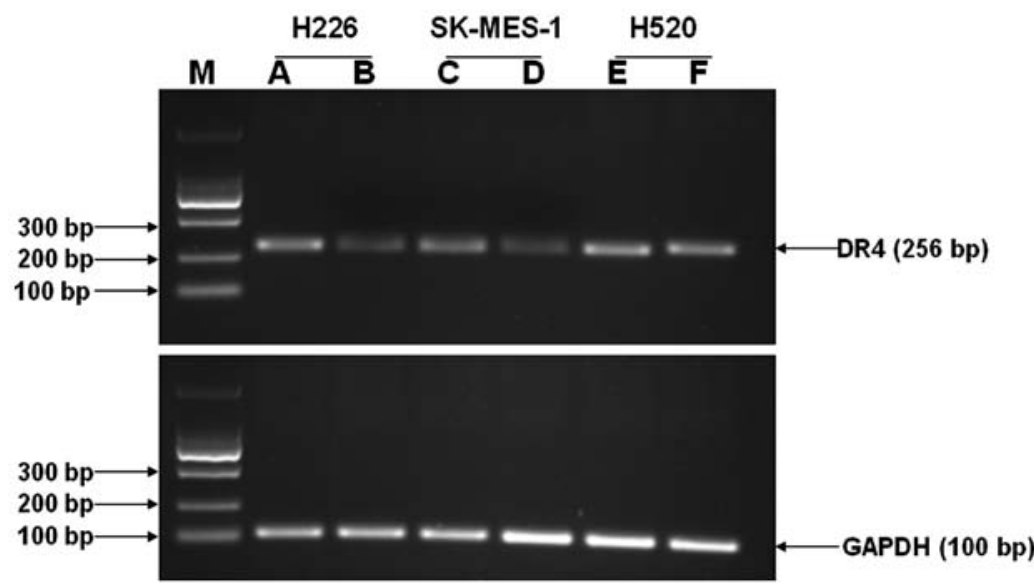

Figure 6. DR4 mRNA expression of H226, SK-MES-1 and H520 cells prior to and following interference with 5-azacytidine. M, DNA marker; B, D and E indcate the control group and $\mathrm{A}, \mathrm{C}$ and $\mathrm{F}$ denote the 5-azacytidine treatment group.

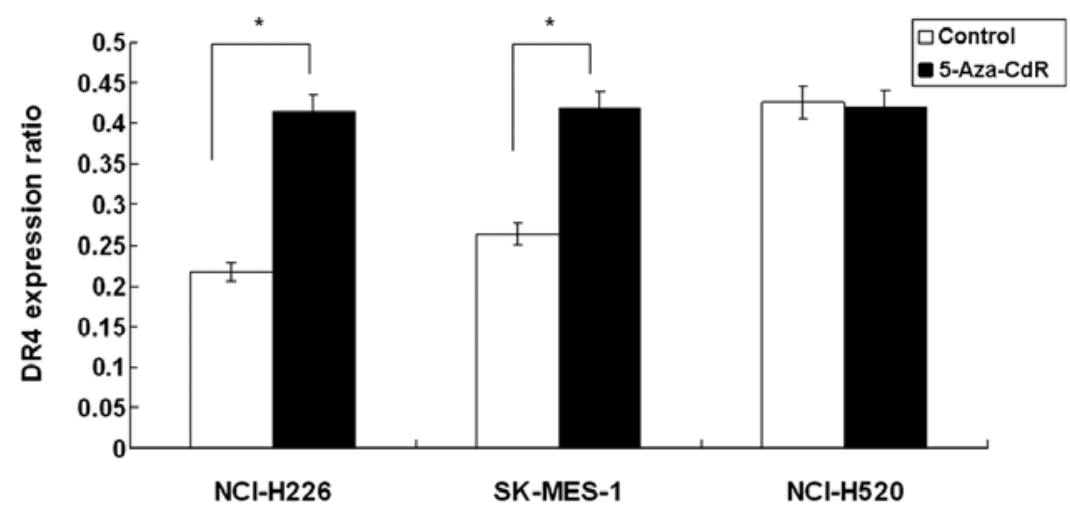

Figure 7. DR4 protein expression of H226, SK-MES-1 and H520 cells.

expression of H226 and SK-MES-1 cells was low whereas that of H520 cells was high. However, following interference with 5-azacytidine, the DR4 protein expression of H226 and SK-MES-1 cells was significantly enhanced compared with the previous levels and the differences were statistically significant $(\mathrm{P}<0.05)$. By contrast, the DR4 protein expression of H520 cells did not markedly change compared with the previous levels and the differences were not statistically significant (Figs. 7 and 8).

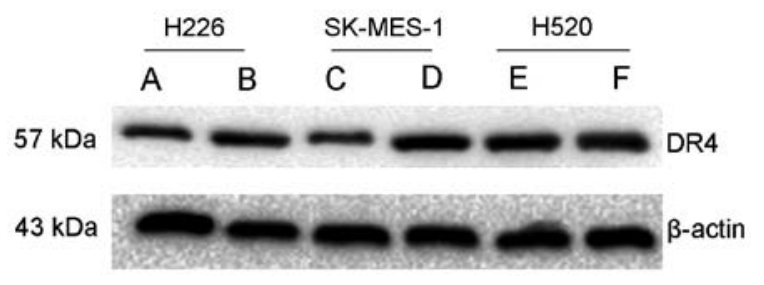

Figure 8. DR4 protein expression of H226, SK-MES-1 and H520 cells prior to and following 5-aza-CDR. A, C and E indicate the control group, and B, D and $\mathrm{F}$ denote the 5-azacytidine treatment group. 
Table III. Proliferation inhibition rate of $\mathrm{H} 226$ cells ( means $\pm \mathrm{SD}, \%$ ).

TRAIL concentration $(\mu \mathrm{g} / \mathrm{ml})$

\begin{tabular}{|c|c|c|c|c|c|c|c|}
\hline Time (h) & $\mathrm{n}$ & 0.01 & 0.05 & 0.10 & 0.50 & 1.00 & 5.00 \\
\hline \multicolumn{8}{|c|}{ Prior to treatment with 5-AZ } \\
\hline 24 & 6 & $2.23 \pm 0.08$ & $5.72 \pm 0.25$ & $7.54 \pm 0.25$ & $10.69 \pm 1.61$ & $19.11 \pm 1.39$ & $31.74 \pm 2.88$ \\
\hline 48 & 6 & $4.81 \pm 0.09$ & $9.02 \pm 0.95$ & $16.57 \pm 1.66$ & $28.23 \pm 2.06$ & $37.32 \pm 3.61$ & $53.87 \pm 3.29$ \\
\hline \multicolumn{8}{|c|}{ Following treatment with 5-AZ } \\
\hline 24 & 6 & $8.15 \pm 0.19^{\mathrm{a}}$ & $17.65 \pm 1.07^{\mathrm{a}}$ & $25.42 \pm 1.46^{\mathrm{a}}$ & $33.04 \pm 2.13^{\mathrm{a}}$ & $48.14 \pm 3.22^{\mathrm{a}}$ & $69.11 \pm 3.67^{\mathrm{a}}$ \\
\hline 48 & 6 & $15.43 \pm 1.05^{\mathrm{b}, \mathrm{c}}$ & $28.51 \pm 1.66^{\mathrm{b}, \mathrm{c}}$ & $41.58 \pm 2.37^{\mathrm{b}, \mathrm{c}}$ & $64.35 \pm 3.83^{\mathrm{b}, \mathrm{c}}$ & $79.40 \pm 3.03^{\mathrm{b}, \mathrm{c}}$ & $89.24 \pm 4.08^{\mathrm{b}, \mathrm{c}}$ \\
\hline
\end{tabular}

5-AZ, 5-azacytidine; compared with the $24 \mathrm{~h}$ group prior to treatment with 5 -AZ. ${ }^{\mathrm{a}}<0.05$; compared with the $48 \mathrm{~h}$ group prior to treatment with $5-\mathrm{AZ},{ }^{\mathrm{b}} \mathrm{P}<0.05$; compared with the 24 h group following treatment with $5-\mathrm{AZ},{ }^{\mathrm{c}} \mathrm{P}<0.05$.

Table IV. SK-MES-1 cell proliferation inhibition rate (means \pm SD, \%).

TRAIL concentration $(\mu \mathrm{g} / \mathrm{ml})$

\begin{tabular}{|c|c|c|c|c|c|c|c|}
\hline Time & $\mathrm{n}$ & 0.01 & 0.05 & 0.10 & 0.50 & 1.00 & 5.00 \\
\hline \multicolumn{8}{|c|}{ Prior to treatment with $5-\mathrm{AZ}$} \\
\hline 24 & 6 & $1.51 \pm 0.12$ & $4.46 \pm 0.31$ & $6.79 \pm 0.41$ & $9.89 \pm 1.47$ & $15.03 \pm 2.77$ & $27.93 \pm 3.35$ \\
\hline 48 & 6 & $3.41 \pm 0.88$ & $8.02 \pm 1.03$ & $14.67 \pm 1.84$ & $25.23 \pm 2.01$ & $32.98 \pm 3.11$ & $48.69 \pm 3.44$ \\
\hline \multicolumn{8}{|c|}{ Following treatment with 5-AZ } \\
\hline 24 & 6 & $7.78 \pm 0.66^{\mathrm{a}}$ & $16.42 \pm 1.20^{\mathrm{a}}$ & $22.81 \pm 1.94^{\mathrm{a}}$ & $32.54 \pm 2.37^{\mathrm{a}}$ & $49.91 \pm 3.08^{\mathrm{a}}$ & $65.11 \pm 3.798$ \\
\hline 48 & 6 & $13.89 \pm 1.23^{\mathrm{b}, \mathrm{c}}$ & $23.36 \pm 1.99^{\mathrm{b}, \mathrm{c}}$ & $45.44 \pm 2.61^{\mathrm{b}, \mathrm{c}}$ & $56.53 \pm 3.28^{b, c}$ & $74.68 \pm 3.71^{\mathrm{b}, \mathrm{c}}$ & $87.18 \pm 4.22^{\mathrm{b}, \mathrm{c}}$ \\
\hline
\end{tabular}

5-AZ, 5-azacytidine; compared with the $24 \mathrm{~h}$ group prior to treatment with 5 - $\mathrm{AZ},{ }^{*} \mathrm{P}<0.05$; compared with the $48 \mathrm{~h}$ group prior to treatment with $5-\mathrm{AZ},{ }^{\mathrm{b}} \mathrm{P}<0.05$; compared with the $24 \mathrm{~h}$ group following treatment with $5-\mathrm{AZ},{ }^{\mathrm{C}} \mathrm{P}<0.05$.

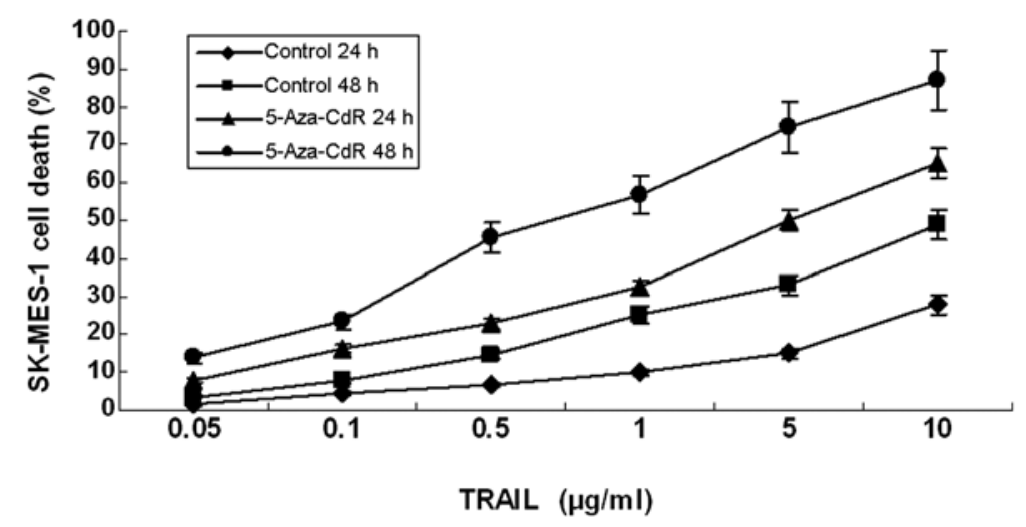

Figure 9. Effect of TRAIL at different concentrations on H226 cell proliferation prior to and following treatment with 5-azacytidine at different time points.

Cell proliferation inhibition rate. Following treatment with TRAIL at different concentrations for $24 \mathrm{~h}, \mathrm{H} 226$ and SK-MES-1 cell growth was inhibited to various degrees, although not significantly. However, after treatment with 5-azacytidine at the same concentration, the cell growth was significantly inhibited as compared with the previous cell growth, and the differences were statistically significant $(\mathrm{P}<0.05)$. The inhibition rates of TRAIL with at the same concentration against cell proliferation increased with the extension of the action time $(\mathrm{P}<0.05)$ (Tables III and IV, and Figs. 9 and 10).

Cell apoptotic rate. Apoptosis of $\mathrm{H} 226$ and SK-MES-1 cells was determined (Tables V and VI). To determine the effect of each group on the cell apoptotic rate, a comparison was made of the 5-azacytidine and control groups. The results 


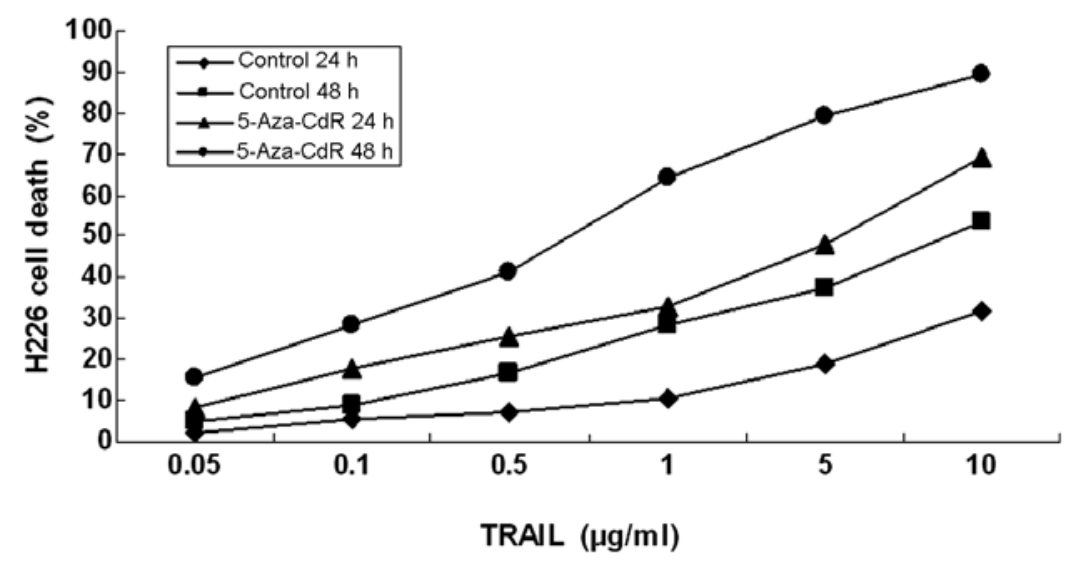

Figure 10. Effect of TRAIL at different concentrations on SK-MES-1 cell proliferation prior to and following treatment with 5-azacytidine at different time points.

Table V. Effect of each group on the apoptosis of H226 cell (means \pm SD, \%).

\begin{tabular}{lcccc}
\hline Group & $\mathrm{n}$ & Early apoptotic rate & Late apoptotic rate & Total apoptotic rate \\
\hline Negative control & 3 & $0.41 \pm 0.05$ & $0.53 \pm 0.03$ & $0.94 \pm 0.10$ \\
5-AZ & 3 & $0.32 \pm 0.02^{\mathrm{a}}$ & $0.62 \pm 0.06^{\mathrm{a}}$ & $1.02 \pm 0.15^{\mathrm{a}}$ \\
TRAIL & 3 & $3.92 \pm 0.11^{\mathrm{b}}$ & $3.18 \pm 0.19^{\mathrm{b}}$ & $7.10 \pm 1.31^{\mathrm{b}}$ \\
5-AZ+TRAIL & 3 & $3.87 \pm 0.23^{\mathrm{b}}$ & $27.33 \pm 1.22^{\mathrm{b}, \mathrm{c}}$ & $31.20 \pm 4.88^{\mathrm{b}, \mathrm{c}}$ \\
\hline
\end{tabular}

5-AZ, 5-azacytidine. Compared with the control group, ${ }^{\mathrm{a}} \mathrm{P}>0.05$; compared with the control group, ${ }^{\mathrm{b}} \mathrm{P}<0.05$; compared with the TRAIL group, ${ }^{\mathrm{c}} \mathrm{P}<0.05$.

Table VI. Effect of each group on the apoptosis of SK-MES-1 cell (means \pm SD, \%).

\begin{tabular}{lcccc}
\hline Group & $\mathrm{n}$ & Early apoptotic rate & Late apoptotic rate & Total apoptotic rate \\
\hline Negative control & 3 & $0.29 \pm 0.02$ & $0.99 \pm 0.10$ & $1.27 \pm 0.15$ \\
5-Aza-CdR & 3 & $0.34 \pm 0.03^{\mathrm{a}}$ & $0.94 \pm 0.08^{\mathrm{a}}$ & $1.21 \pm 0.19^{\mathrm{a}}$ \\
TRAIL & 3 & $4.12 \pm 0.15^{\mathrm{b}}$ & $3.78 \pm 0.35^{\mathrm{b}}$ & $7.90 \pm 1.46^{\mathrm{b}}$ \\
5-AZ+TRAIL & 3 & $14.86 \pm 0.41^{\mathrm{b}, \mathrm{c}}$ & $13.37 \pm 1.31^{\mathrm{b}, \mathrm{c}}$ & $28.23 \pm 3.87^{\mathrm{b}, \mathrm{c}}$ \\
\hline
\end{tabular}

5-AZ, 5-azacytidine. Compared with the control group, ${ }^{\mathrm{a}} \mathrm{P}>0.05$; compared with the control group, ${ }^{\mathrm{b}} \mathrm{P}<0.05$; compared with TRAIL group, ${ }^{\mathrm{c}} \mathrm{P}<0.05$.

showed that, the differences between the groups were not statistically significant, suggesting that $5 \mu \mathrm{mol} / 15-\mathrm{AZ}$ has no significant apoptotic effect on cells. However, the TRAIL and 5-AZ + TRAIL groups induced apoptotic effects on the cells. This induced apoptotic effect on the cells in the $5-A Z+$ TRAIL group was significantly higher than that of the TRAIL group, and the difference was statistically significant $(\mathrm{P}<0.05)$ (Figs. 11 and 12).

\section{Discussion}

For DNA methylation modification, under the catalysis of methyltransferase, $\mathrm{C}$ is integrated with methyl to form ${ }^{\mathrm{m}} \mathrm{C}$, while the integration of methylation ${ }^{\mathrm{m}} \mathrm{CpG}$ with DNA methyl-binding domain protein can indirectly block the binding of transcription initiation elements with the DNA promoter region, to regulate the gene expression (26-28). The gene promoter region $\mathrm{CpG}$ island is generally found in the non-methylation status. An abnormally high expression can directly or indirectly block gene transcription, resulting in silencing or a function of the cell cycle regulatory gene, DNA repair gene, apoptosis gene, tumor suppressor gene and other related genes, which may be one of the main factors inducing tumors $(29,30)$. In lung carcinoma and other carcinoma cells, the abnormal increase in the methylation levels of some gene $\mathrm{CpG}$ island regions is their main characteristic (31). For colorectal cancer, previous findings have shown an abnormal methylation is a characteristic factor in the regulation of CPT-11 metabolic enzyme change. The presence of methylation in UGT1A1 gene promoters of colorectal cancer cells is an important mechanism for silencing of the UGT1A1 gene expression and also a target to identify the regulatory mechanism for CPT-11 resistance and reversal 

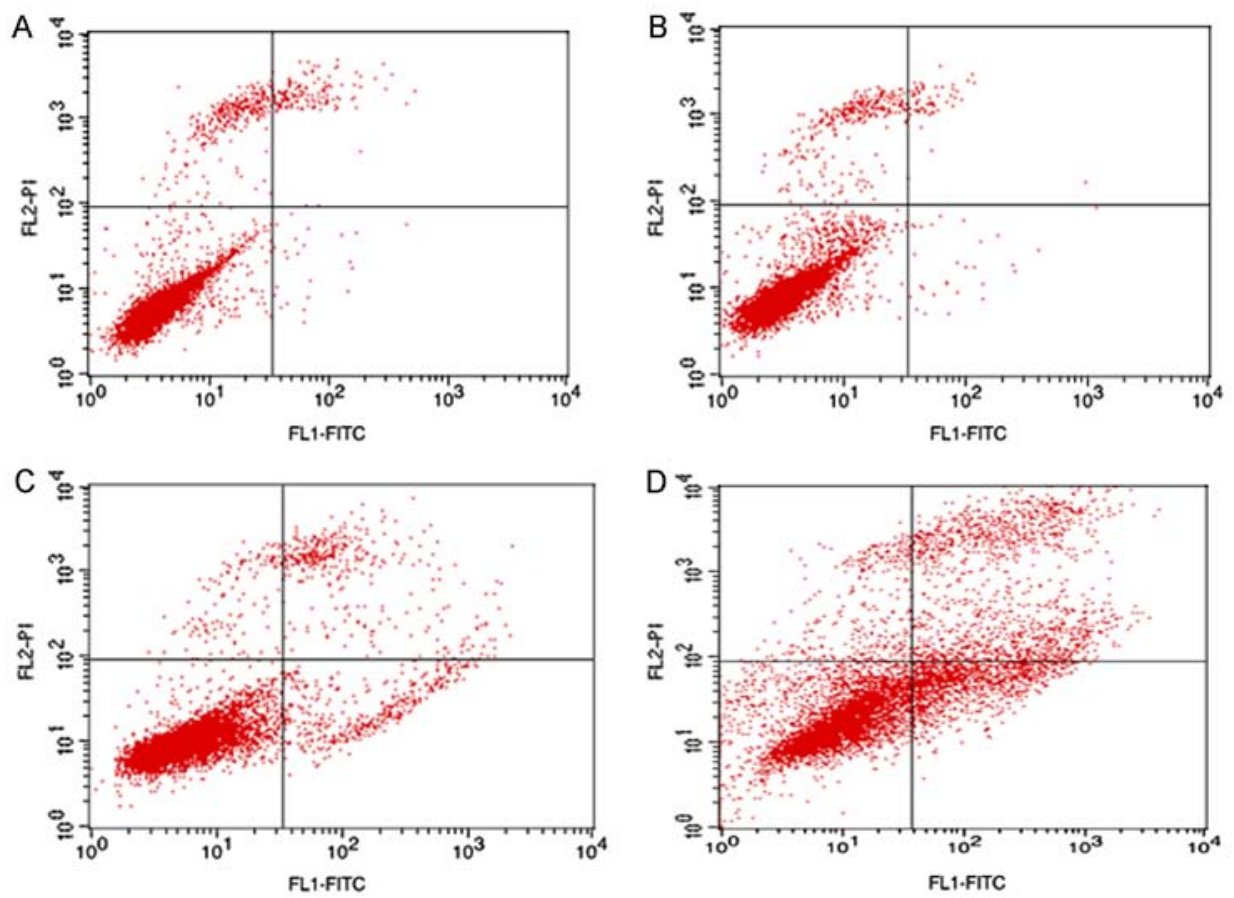

Figure 11. Apoptotic rate of H226 cells detected by Annexin V/PI double-stained flow cytometry. (A) Control group, (B) 5-AZ group, (C) TRAIL group and (D) 5-AZ + TRAIL group. 5-AZ, 5-azacytidine.
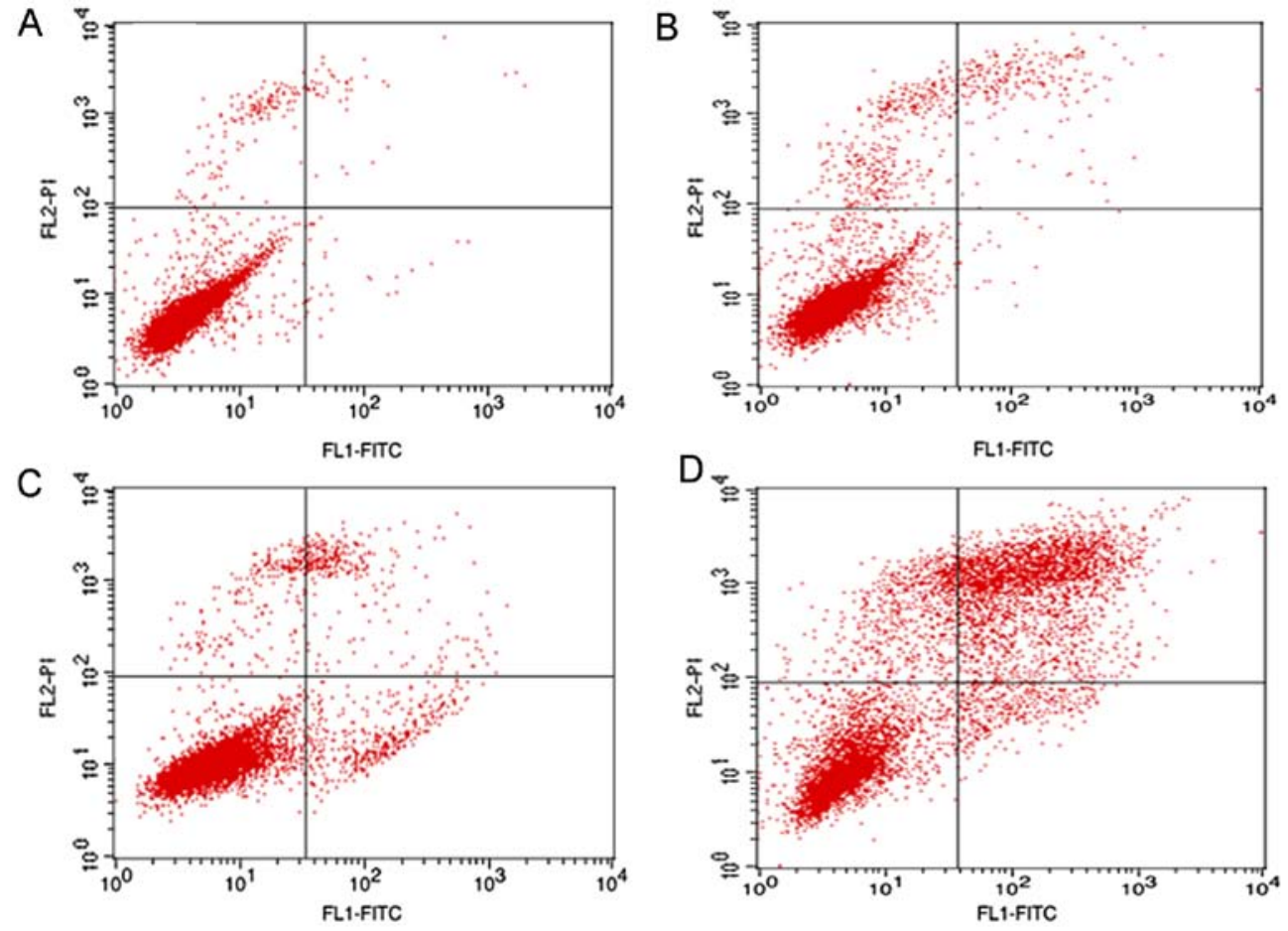

Figure 12 Survival rate of SK-MES-1 cells detected by Annexin V/PI double-stained flow cytometry. (A) Control group, (B) 5-AZ group, (C) TRAIL group and (D) 5-AZ + TRAIL group. 5-AZ, 5-azacytidine.

resistance $(32,33)$. DNA methylation status is reversible and the genes with expression silencing or a function due to the hypermethylation status can restore their expression through the DNA methyltransferase enzyme inhibitor. Currently, the DNA methyltransferase inhibitor has made significant progress in the treatment of hematological malignancies, for example, decitabine, also known as 5-aza-2'-deoxycytidine, has been approved by the FDA for the treatment of myelodysplastic syndrome and acute leukemia, and has achieved satisfactory therapeutic effect. The drug at a low dose can maximize the inhibitory effect of DNA demethylation, while the drug at a high dose shows cytotoxicity. Therefore, drug treatment at s 
low dose can maximize the therapeutic effect and the most significant finding was that it can effectively remove DNA methylation, to re-express many inactivated genes.

TRAIL, a new member of the superfamily of TNF, has been recently identified, and TRAIL-induced apoptosis is not dependent on p53 status. Unlike radio- and chemotherapy-induced apoptosis mechanisms, TRAIL has some value for chemotherapy-resistant tumors. As a result, TRAIL has been investigated as a potential antineoplastic agent. However, tolerance is a major obstacle to TRAIL-induced apoptosis and it has been identified that this type of apoptosis may be associated with the hypermethylation of DR4 gene promoters (15-19). However, whether alteration of DR4 gene promoter methylation status affects DR4 expression to increase the tumor cell apoptosis induced by TRAIL remains to be determined. Thus, the focus of this study was on lung squamous carcinoma and whether the DR4 gene promoter methylation status affected the TRAIL-induced apoptosis in lung squamous carcinoma cells.

The results showed that the probability of DR4 gene methylation was relatively high, at $80.6 \%$, among patients with lung squamous carcinoma while the methylation status did not correlate with the clinicopathological characteristics of patients with lung squamous carcinoma $(\mathrm{P}>0.05)$. To confirm the relationship between methylation status and DR4 expression, immunohistochemistry was employed to detect DR4 expression for the 36 patients. The result showed that $58.3 \%$ of the patients with lung squamous carcinoma had a low DR4 expression, which may be associated with their gene promoter methylation. At the same time, the prognosis of the patients with lung squamous carcinoma exhibiting a high DR4 expression was lower than that of the patients with a low expression.

To determine the effect of DR4 gene promoter methylation status on the TRAIL-induced apoptosis of lung squamous carcinoma cells, we conducted in vitro experiments. DR4 gene promoter region $\mathrm{CpG}$ islands of H226 and SK-MES-1 cells exhibited a positive methylation status and the expression of mRNA and proteins were low, whereas the DR4 gene promoter region $\mathrm{CpG}$ islands of $\mathrm{H} 520$ cells exhibited a non-methylation status and the expression of their mRNA and proteins was high. Following treatment with 5-Aza-CdR, DR4 genes of H226 and SK-MES-1 exhibited a non-methylation status and the expression of their mRNA and proteins increased significantly $(\mathrm{P}<0.05)$, whereas $\mathrm{H} 520$ cells in the non-methylation status did not markedly alter. MTT assay and flow cytometry confirmed that H226 and SK-MES-1 cells are TRAIL-insensitive. Following treament with 5-Aza-CdR, the sensitivity of these two lung squamous carcinoma cells to TRAIL significantly increased compared with the previous sensitivity identified $(\mathrm{P}<0.05)$. The findings suggest that DR4 gene promoter methylation may downregulate the expression level of the DR4 gene, resulting in decreased sensitivity to TRAIL and affecting the efficacy of TRAIL on lung squamous carcinoma.

In conclusion, a low dose of 5-Aza-CdR is capable of reversing the methylation status and may improve the efficacy of TRAIL on lung squamous carcinoma. A low dose of 5-AzaCdR has no toxicity, while TRAIL has a high selectivity and high efficiency induction of apoptosis in a variety of carcinoma cells, which also has no significant toxicity on normal tissues. Therefore, the combination of 5-Aza-CdR and TRAIL may be a novel therapeutic strategy for the treatment of lung squamous carcinoma and is expected to be useful in the treatment of lung squamous carcinoma. However, the present study results are limited to the in vitro experiment and only involve the DR4 gene, while the reason for TRAIL resistance being affected may be associated with the change of molecules associated with the tumor necrosis pathway apoptosis (such as BAX, $\mathrm{Bcl}-2, \mathrm{Bcl}-\mathrm{XL}$, and caspase-3,8,9). Therefore, to examine the treatment effect of 5-Aza-CdR combined with TRAIL in lung squamous carcinoma, animal experiments and stage I/II clinical tests should be carried out to verify the results and whether the change of the methylation status of associated molecules has an impact on the effect of TRAIL-induced lung squamous carcinoma apoptosis may be detected.

\section{References}

1. Molina JR, Yang P, Cassivi SD, Schild SE and Adjei AA: Non-small cell lung cancer: Epidemiology, risk factors, treatment, and survivorship. Mayo Clin Proc 83: 584-594, 2008.

2. Jemal A, Siegel R, Ward E, Hao Y, Xu J and Thun MJ: Cancer statistics, 2009. CA Cancer J Clin 59: 225-249, 2009.

3. Azzoli CG, Baker S Jr, Temin S, Pao W, Aliff T, Brahmer J, Johnson DH, Laskin JL, Masters G, Milton D, et al; American Society of Clinical Oncology: American Society of Clinical Oncology Clinical Practice Guideline update on chemotherapy for stage IV non-small-cell lung cancer. J Clin Oncol 27: 6251-6266, 2009

4. Zhang X, Zhao J, Zhu W, Gou H, Cao D, Yang Y, Huang Y and Yi C: Synergistic effect of subtoxic-dose cisplatin and TRAIL to mediate apoptosis by down-regulating decoy receptor 2 and up-regulating caspase-8, caspase- 9 and Bax expression on NCI-H460 and A549 Cells. Iran J Basic Med Sci 16: 710-718, 2013.

5. Stegehuis JH, de Wilt LH, de Vries EG, Groen HJ, de Jong S and Kruyt FA: TRAIL receptor targeting therapies for non-small cell lung cancer: Current status and perspectives. Drug Resist Updat 13: 2-15, 2010.

6. Luster TA, Carrell JA, McCormick K, Sun D and Humphreys R: Mapatumumab and lexatumumab induce apoptosis in TRAIL-R1 and TRAIL-R2 antibody-resistant NSCLC cell lines when treated in combination with bortezomib. Mol Cancer Ther 8: 292-302, 2009.

7. Jung Y-H, Heo J, Lee YJ, Kwon TK and Kim Y-H: Quercetin enhances TRAIL-induced apoptosis in prostate cancer cells via increased protein stability of death receptor 5 . Life Sci 86: 351-357, 2010.

8. Schaefer U, Voloshanenko O, Willen D and Walczak H: TRAIL: A multifunctional cytokine. Front Biosci 12: 3813-3824, 2007.

9. Dillon CP, Oberst A, Weinlich R, Janke LJ, Kang TB, Ben-Moshe T, Mak TW, Wallach D and Green DR: Survival function of the FADD-CASPASE-8-cFLIP(L) complex. Cell Reports 1: 401-407, 2012.

10. Maldonado ME, Bousserouel S, Gossé F, Lobstein A and Raul F: Implication of NF- $\mathrm{KB}$ and $\mathrm{p} 53$ in the expression of TRAIL-death receptors and apoptosis by apple procyanidins in human metastatic SW620 cells. Biomedica 30: 577-586, 2010.

11. Haag C, Stadel D, Zhou S, Bachem MG, Möller P, Debatin KM and Fulda S: Identification of c-FLIPL and c-FLIPS as critical regulators of death receptor-induced apoptosis in pancreatic cancer cells. Gut 60: 225-237, 2010.

12. Falschlehner $\mathrm{C}$, Emmerich $\mathrm{CH}$, Gerlach B and Walczak $\mathrm{H}$ : TRAIL signalling: Decisions between life and death. Int $\mathbf{J}$ Biochem Cell Biol 39: 1462-1475, 2007.

13. Earel JK Jr, VanOosten RL and Griffith TS: Histone deacetylase inhibitors modulate the sensitivity of tumor necrosis factorrelated apoptosis-inducing ligand-resistant bladder tumor cells. Cancer Res 66: 499-507, 2006.

14. Papageorgiou A, Lashinger L, Millikan R, Grossman HB, Benedict W, Dinney CP and McConkey DJ: Role of tumor necrosis factor-related apoptosis-inducing ligand in interferoninduced apoptosis in human bladder cancer cells. Cancer Res 64: 8973-8979, 2004.

15. Lee KH, Lim SW, Kim HG, Kim DY, Ryu SY, Joo JK, Kim JC and Lee JH: Lack of death receptor 4 (DR4) expression through gene promoter methylation in gastric carcinoma. Langenbecks Arch Surg 394: 661-670, 2009. 
16. Bae SI, Cheriyath V, Jacobs BS, Reu FJ and Borden EC: Reversal of methylation silencing of Apo2L/TRAIL receptor 1 (DR4) expression overcomes resistance of SK-MEL-3 and SK-MEL-28 melanoma cells to interferons (IFNs) or Apo2L/TRAIL. Oncogene 27: 490-498, 2008.

17. Suzuki M, Shigematsu H, Shivapurkar N, Reddy J, Miyajima K, Takahashi T, Gazdar AF and Frenkel EP: Methylation of apoptosis related genes in the pathogenesis and prognosis of prostate cancer. Cancer Lett 242: 222-230, 2006.

18. Horak P, Pils D, Haller G, Pribill I, Roessler M, Tomek S, Horvat R, Zeillinger R, Zielinski C and Krainer M: Contribution of epigenetic silencing of tumor necrosis factor-related apoptosis inducing ligand receptor 1 (DR4) to TRAIL resistance and ovarian cancer. Mol Cancer Res 3: 335-343, 2005.

19. Eramo A, Pallini R, Lotti F, Sette G, Patti M, Bartucci M, Ricci-Vitiani L, Signore M, Stassi G, Larocca LM, et al: Inhibition of DNA methylation sensitizes glioblastoma for tumor necrosis factor-related apoptosis-inducing ligand-mediated destruction. Cancer Res 65: 11469-11477, 2005.

20. Keating GM: Azacitidine: A review of its use in higher-risk myelodysplastic syndromes/acute myeloid leukaemia. Drugs 69: 2501-2518, 2009.

21. Cataldo VD, Cortes J and Quintás-Cardama A: Azacitidine for the treatment of myelodysplastic syndrome. Expert Rev Anticancer Ther 9: 875-884, 2009.

22. Kaminskas E, Farrell A, Abraham S, Baird A, Hsieh LS, Lee SL, Leighton JK, Patel H, Rahman A, Sridhara R, et al; FDA: Approval summary: Azacitidine for treatment of myelodysplastic syndrome subtypes. Clin Cancer Res 11: 3604-3608, 2005.

23. Vaitkienè $P$, Skiriutė $D$, Skauminas $K$ and Tamašauskas $A$ : Associations between TFPI-2 methylation and poor prognosis in glioblastomas. Medicina (Kaunas) 48: 345-349, 2012.

24. Dong SW, Ma L, Xu N, Yan HQ, Liu HY, Li YW and Zhang P: Research on the reactivation of Syk expression caused by the inhibition of DNA promoter methylation in the lung cancer. Neoplasma 58: 89-95, 2011.
25. Lin CT, Lai HC, Lee HY, Lin WH, Chang CC, Chu TY, Lin YW, Lee KD and Yu MH: Valproic acid resensitizes cisplatin-resistant ovarian cancer cells. Cancer Sci 99: 1218-1226, 2008.

26. Avraham A, Cho SS, Uhlmann R, Polak ML, Sandbank J, Karni T, Pappo I, Halperin R, Vaknin Z, Sella A, et al: Tissue specific DNA methylation in normal human breast epithelium and in breast cancer. PLoS One 9: e91805, 2014.

27. Yan $\mathrm{H}$ and Sun J: Methylation status of WWOX gene promoter CpG islands in epithelial ovarian cancer and its clinical significance. Biomed Rep 1: 375-378, 2013.

28. Baylin SB and Jones PA: A decade of exploring the cancer epigenome - biological and translational implications. Nat Rev Cancer 11: 726-734, 2011

29. Tan S, Sun C, Wei X, Li Y, Wu Y, Yan Z, Feng F, Wang J and Wu Y: Quantitative assessment of lung cancer associated with genes methylation in the peripheral blood. Exp Lung Res 39: 182-190, 2013.

30. Kupčinskaitè-Noreikienè R, Skiecevičienè J, Jonaitis L, Ugenskienė R, Kupčinskas J, Markelis R, Baltrénas V, Sakavičius L, Semakina I, Grižas S, et al: CpG island methylation of the MLH1, MGMT, DAPK, and CASP8 genes in cancerous and adjacent noncancerous stomach tissues. Medicina (Kaunas) 49: 361-366, 2013.

31. Balgkouranidou I, Liloglou T and Lianidou ES: Lung cancer epigenetics: Emerging biomarkers. Biomarkers Med 7: 49-58, 2013.

32. Xie F-W, Peng Y-H, Wang W-W, Chen X, Chen X, Li J, Yu ZY and Ouyang XN: Influence of UGT1A1 gene methylation level in colorectal cancer cells on the sensitivity of the chemotherapy drug CPT-11. Biomed Pharmacother 68: 825-831, 2014.

33. Xie F-W, Peng Y-H, Chen X, Chen X, Li J, Yu ZY, Wang WW and Ouyang XN: Regulation and expression of aberrant methylation on irinotecan metabolic genes CES2, UGT1A1 and GUSB in the in-vitro cultured colorectal cancer cells. Biomed Pharmacother 68: 31-37, 2014. 